\title{
Key points of the new Spanish Patent Act
}

\author{
"...on 21 December 2016, the Spanish General Council of the \\ Judiciary issued an agreement to confer exclusive jurisdiction \\ to some specific courts of Barcelona, Madrid and Valencia \\ regarding patents, trademarks and designs ... This agreement \\ will enter into force on 1 April 2017..."
}

First draft submitted: 8 January 2017; Accepted for publication: 19 January 2017; Published online: 1 March 2017

Keywords: European Patent Convention $\bullet$ patent limitation $\bullet$ patent modification $\bullet$ patents - postgranting opposition $\bullet$ protective letter $\bullet$ Spain $\bullet$ specialized courts $\bullet$ strong patents - utility models

The new Spanish Patent Act, Act 24/2015, was adopted on 24 July 2015 and published in the Spanish Official Bulletin on 25 July 2015. It will enter into force on 1 April 2017 [1].

This new Spanish Patent Act (New Sp. PA) strengthens Spanish national patents, aligns the Spanish legislation with the last amendments of the European Patent Convention (EPC Review Act of 29 November 2000, which entered into force on 13 December 2007), introduces changes in the litigation procedure to specialize it and clarifies the legislation in view of the effective application of some aspects of the current Patent Act 11/1986 (Current Sp. PA) [2].

This article is not intended to be comprehensive but aims to illustrate some of the most important novelties introduced by the New Sp. PA.

\section{Abolishment of weak patents}

The New Sp. PA establishes a compulsory substantive examination of patent applications. In contrast, under the Current Sp. PA, applicants can decide whether the granting of their Spanish patents undergoes or not a substantive examination. The current system seeks to benefit small and medium companies, but it creates a market full of defense patents.

\section{New postgranting opposition procedure}

The New Sp. PA introduces the possibility to file oppositions against national patents in the 6 months following the publication of the patent granting in the Spanish Intellectual Property Bulletin. Instead, under the Current Sp. PA, oppositions can be filed during the prosecution of the patent application (only when it is prosecuted with a substantive examination). This new measure aims to accelerate the prosecution of the national patents. In any event, the New Sp. PA establishes the possibility of third parties to file observations after the publication of the patent application (now, included in the prosecution without a substantive examination) where they can refer to any aspect related to the patentability of the invention.

\section{Modification of national patents after their granting}

In line with the possibilities introduced by EPC Review Act of 29 November 2000 for European patents [3], the New Sp. PA includes the possibility for the patentee of a national patent to modify the patent after its granting. In particular, the New Sp. PA includes the following possibilities for the patentee: request for revocation or limitation of national patents before the Spanish Patents and Trademarks Office by modifying their claims at any time and request for limitation of the national patent in the framework of litigation where the validity of the patent is challenged before the court dealing with
Teresa Mercadal Menchaca Bird \& Bird, Madrid, Spain tmm@twobirds.com

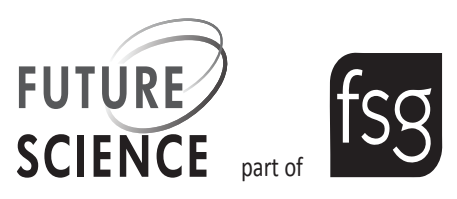


the case. In addition, it is contemplated that courts can declare the partial nullity of claims in litigations where this is requested in a lawsuit or in a counterclaim. These revocations and limitations will have retroactive effect. In contrast, under the Current Sp. $\mathrm{PA}$, the request for revocation or limitation of national patents by modifying their claims requested by the patentee is neither possible before the Spanish Patents and Trademarks Office nor before the courts. The patentee can only renounce the whole of the patent or to some of the claims of a patent without retroactive effect. Furthermore, Spanish courts have already dealt with limitations of European patents in application of Article 138.3 EPC, although neither the Current Sp. PA nor the Spanish Civil Procedural Act establishes anything in this regard. Accordingly, Spanish courts are bewildered with the limitation of European patents in application of Article 138.3 (see, among others, Court Order 6 June 2011, docetaxel case [4]: the first case of limitation of a validation of a European patent in Spain). The New Sp. PA establishes the procedure to follow in order to make such limitations in litigation, both for national patents and Spanish validations of European patents.

\section{Specialized courts}

The New Sp. PA foresees that only commercial courts specialized in patents can deal with patent litigation in the first instance stage. Trademarks and Design Acts refer to the Patent Act regarding jurisdiction and procedural rules. Therefore, from 1 April 2017 only commercial courts specialized in patents, trademarks and designs can deal with patents, trademarks and designs litigation, respectively. By the time being, there are only commercial courts specialized in patents, designs and trademarks in Barcelona. Recently, on 21 December 2016, the Spanish General Council of the Judiciary issued an agreement to confer exclusive jurisdiction to some specific courts of Barcelona, Madrid and Valencia regarding patents, trademarks and designs. This agreement will enter into force on 1 April 2017 together with the entry into force of the New Sp. PA.

\footnotetext{
"The New Sp. PA introduces the requirement of requesting a report on the state of the art to exercise actions based on utility models applied as of the entry into force of the New Sp. PA."
}

\section{Protective letters}

The New Sp. PA explicitly includes the possibility of filing protective letters in order to avoid the granting of ex parte preliminary injunctions. This protective letter is served to the patentee and, in case the ex parte preliminary injunctions request is submitted in the following 3 months, the court may, at its discretion, consider deciding on them with or without the preliminary hearing of the defendant. If the claimant considers that the protective letter was filed before a noncompetent court, he/she should file the ex parte preliminary injunctions request before the competent court but should communicate the existence of the protective letter and identify the court dealing with it. This possibility exists in other European countries, such as Germany. The Current Sp. PA does not contain any provision allowing the use of protective letters. Nevertheless, since 2013 some potential defendants of ex parte preliminary injunctions in the framework of patent infringement proceedings tried to file them before the Spanish courts, with different outcomes. Commercial Courts of Barcelona have admitted the filing of protective letters (among others, by Orders dated 18 January 2013 - celecoxib case [5], 3 June 2013 - zoledronic acid case - [court order not available for the public]) under certain conditions while Commercial Courts of Madrid (Order dated 29 January 2014) rejected the filing of a protective letter arguing that this possibility is not contemplated in our domestic law and that there are alternative possibilities, like the request of a declaration of noninfringement.

\section{Reinforcement of utility models}

The New Sp. PA extends the scope of protection of utility models. The Current Sp. PA only refers to inventions over objects. In contrast, the new scope of protection is extended to any product, except pharmaceutical products and biological material, which are explicitly excluded. Methods are excluded both in the Current Sp. PA and in the New Sp. PA. Unlike the Current Sp. PA, the New Sp. PA equates the state of the art between patents and utility models. The main difference in the substantive requirements between patents and utility models is the inventive step level, which is lower in the case-of-utility models. Regarding the prosecution procedure, the New Sp. PA maintains a procedure: (i) without a report on the state of the art and an examination of the substantive requirements (novelty, inventive step and industrial application) and (ii) with the possibility to file oppositions during the prosecution. The New Sp. PA introduces the requirement of requesting a report on the state of the art to exercise actions based on utility models applied as of the entry into force of the New Sp. PA.

The New Sp. PA Act does not include any reference to the possibility of Spain's joining the enhanced cooperation on a unitary patent and the Unified Patent Court. 
Financial \& competing interests disclosure

The author has no relevant affiliations or financial involvement with any organization or entity with a financial interest in or financial conflict with the subject matter or materials discussed in the manuscript. This includes employment,

\section{References}

1 Judicial Power, Government of Spain. Consolidated Legislation BOE-A-2015-8328. www.boe.es

2 Judicial Power, Government of Spain Consolidated legislation BOE-A-1986-7900.

www.boe.es consultancies, honoraria, stock ownership or options, expert testimony, grants or patents received or pending, or royalties.

No writing assistance was utilized in the production of this manuscript.

3 The European Patent Convention. www.epo.org

4 Judicial Power, Government of Spain. www.poderjudicial.es

5 Judicial Power, Government of Spain. www.poderjudicial.es 